\title{
COALESCENCE OF TEETH IN FISHES
}

\author{
HERALDO A. BRITSKI 1 \\ ROBERTO D. ANDREUCCI 2 \\ NAẼRCIO A. MENEZES 1 \\ JOSE CARNEIRO
}

\begin{abstract}
In this paper the concept of coalescence of teeth previously defined for the Tetraodontoid fishes is extended to some other teleostomes. Comments are made on the «dentigerous plates》 of non-teleostomian fishes and on the dermal plates bearing odontodes found in some fossil groups.
\end{abstract}

\section{INTRODUCTION}

Teeth are structures which evolved in the mouth of the ancestral gnathostome, and are unknown in both lower chordates and agnathous vertebrates, both Recent and fossil.

In «typical» mammal teeth, the best studied of all vertebrate teeth, two layers are recognized, an external thin and very hard layer, the enamel, and an internal, less hard, thicker layer, the dentine. Finally included within the dentine is the pulp chamber filled by soft tissue containing blood vessels and nerves.

Through studies of embryonic development in mammals it is known that a tooth first arises as an ectodermal invagination forming a cap-shaped mass over mesoderm cells which are in the process of becoming organized, and their accompanying blood vessels and nerves. The mesoderm cells which form odontoblasts lay down a protein matrix which, in turn, incorporates minerals and forms or becomes the dentine. During this process the odontoblasts progressively shift towards the interior of the tooth, and finally are enclosed within the pulp cavity, leaving only fine tubules oriented perpendicular to the surface of the tooth penetrating the dentine. The enamel layer is secreted by ectodermal cells on the outer surface of the dentine.

1. Museu de Zoologia, Universidade de São Paulo, C.P. 7172, SP. Bolsista do Conselho Nacional de Desenvolvimento Científico e Tecnológico (H.A.B.).

2. Departamento de Morfologia, Faculdade de Odontologia de São José dos Campos, UNESP, C.P. 314, S. José dos Campos, SP.

3. Departamento de Histologia, Instituto de Ciências Biomédicas da Universidade de São Paulo, C.P. 4365, São Paulo, SP. 
In fishes, however, the outermost layer of the tooth is usually formed by the joint action of ectodermal and mesodermal cells. Through this process the so called enameloid tissues are formed. In teleosts, the teeth are only rarely implanted in alveoli. As soon as teeth are fully formed they are displaced to the surface where they replace older ones which are shed, and the replacement teeth are joined to the jaw bones through the deposition of attachment bone. In general at least several successive generations of functional teeth are produced during a fish's life.

Teeth as individual elements have the basic structure described above, and can be easily recognized and couted. That factor and the relative stability of adult tooth number in jaw bones lead to teeth often being used as an important diagnostic character for species and higher taxa in fishes.

In some fish groups the teeth are frequently not distinct, but rather coalesce into a complex in which the basic structure described above is not readily recognizable. The term coalescence has been used by ichthyologists to designate the integration of the individual jaw teeth into a cutting or crushing plate that is found in various teleosts: Tetraodontoidea (in a recent classification of the Tetraodontiformes, Tyler, 1980, the suborder Tetraodontoidei is considered as a superfamily, Tetraodontoidea), Scaridae, and Oplegnathidae (see for instance Gregory, 1933: 424). However, this somewhat imprecise term has not been used by many morphologists to designate this peculiar integration of teeth.

In a recent paper (Andreucci et al., 1982) coalescence of teeth in the Tetraodontoidea was described structurally and defined. Information subsequently acquired has allowed us to reinforce and broaden the concepts expressed in that paper. It is our purpose to demonstrate that coalescence has a much wider taxonomic distribution, occurring in many apparently not closely related fish groups, including some non-teleosts.

In order to facilitate our introduction to the subject we will summarize the main findings of the 1982 paper which we partially modify herein, and use the same figures. We then consider «tooth plates» in non-teleost groups which we think are true coalescent teeth. As a corollary of these studies we discuss briefly the morphology of the dermal plates found in some fossil fish groups which bear odontoid structures.

\section{COALESCENCE IN THE TETRAODONTOIDEA}

The superfamily Tetraodontoidea includes four families: Triodontidae, Tetraodontidae, Diodontidae, and Molidae. The Triodontidae is represented by just one Recent species, Triodon macropterus from the Indo-Pacific; the remaining families are represented by more numerous species, and have a much wider geographic distribution (Atlantic, Pacific and Indian Oceans). In our studies we have examined specimes of Triodon, three genera of Tetraodontidae (Colomesus, Lagocephatus, 
and Sphoeroides), two genera of Diodontidae (Chilomycterus and Diodon), and three genera currently assigned to the Molidae (Mola, Masturus, and Ranzania).

As a model for the structures and basic mechanisms involved in the process of coalescence we briefly describe the jaws of Sphoeroides greeleyi examined via routine anatomical and histological methods. Once the process of coalescence in S. greeleyi is understood, that model can be applied to other groups, since most of the morphological processes and systems found in those groups are, as a whole, recognizable in Sphoeroides.

Both the upper and the lower jaws of Sphoeroides greeleyi have distinct median symphyseal sutures; the exposed inner and outer surfaces of both jaws are smooth, bright white, and together with the teeth look like two large incisors. A paramedian section of each jaw (Fig. 1) show: (1) a basal portion in which parallel laminae can be recognized (OBP, in section they have the appearence of bars); (2) a compact distal portion formed by the same tissue (ODP); (3) a «dental cavity» inside the jaw, filled with soft tissue in which developing denticles (EPF) can be seen; (4) «pieces» of highly calcified tissue within the distal portion named «denticles» by some authors. A «masticatory surface» and the anteroexternal and posterointernal walls are also distinguishable.

Cuvier (1836/49: 333), in describing tetraodontoid teeth for the first time stated (freely translated) that «instead of visible teeth the jaws are made of an ivory-like substance internally divided in laminae which, as a whole, look like a parrot-beak and in essence is composed of true teeth assembled and successively renewed once they are worn away as a consequence of food-crushing». It was already known that such laminae or pieces formed within the dental cavity attain maximum mineralization and hardness as they get closer to the masticatory surface. Several authors (Owen, 1840/45; Tomes, 1914; Tretjakoff, 1926; Pflugfelder, 1930; Bertin, 1958; and more recently Tyler, 1980) have presented detailed morphological descriptions of the premaxillary and dentary bones of different species of Tetraodontoidea and summarized data on the shape, number, disposition, constitution, and genesis of the «hard pieces» fitting into those bones. Information was given using a variety of names other than denticles, laminae and pieces, as used by Andreucci et al. (1982) for such structures as teeth, lamellae, plates and elements. The previous multiplicity of names is a good indication of the difficulty previous authors had in understanding the actual development and morphology of the laminae. In the Tetraodontoidea tooth derived structures and supporting bones were never identified and defined properly, and their morphological relationships were never studied in detail. Neither was the evolutionary process leading to the formation of the complex structures (highly specialized for cutting and/or crushing food) evaluated. In most cases no attempt was made to understand the peculiar arrangement of the laminae within the premaxillaries and dentaries. Studies on the masticatory apparatus of representatives of the group using routine histological and anatomical 
methods by Andreucci (1966, 1968a, 1968b), Andreucei \& Britski (1969a, 1969b, 1970, 1971, 1975), Britski \& Andreucci (1971), and Andreucci et al. (1974) were primarily limited to the macro-and microscopic description of the laminae and their arrangement in the bones, and to an analysis of their function in the masticatory process.

The first step in solving the problem was taken by Andreucci (1970) who discovered that the tooth-bearing bones (premaxillaries and dentaries) of Sphoeroides testudineus are not formed by bony tissue but by osteodentine. Further observations led to the conclusion that all of the other elements of the skeleton (cranium and axial) except for the jaw bones are formed by bony tissue just as in other teleosts. Subsequently, Andreucci \& Blumen (1971), through autoradiographic studies, concluded that the hard pieces found within the jaws of $S$. testudineus are formed by enameloid and not dentine and/or enamel, as has been suggested by previous authors.

Besides routine anatomical and histological methods we also have used autoradiographic techniques in the present study. Several specimens of Sphoeroides greeleyi received subcutaneous injections of $3 \mathrm{H}$ proline and were killed at different time intervals after the incorporation of the substance into the body tissues. In this technique the radioactive material is incorporated only in areas of the genesis of new tissues. Such regions of the bone (Fig. 1, OZ) are represented by black dots, and one of these areas can be clearly seen around the external margin of the basal portion (dotted areas). The illustrated section comes from specimens killed two days after injection. Sections from specimens killed at progressively longer time intervals after the injection have this dotted band increasingly deeper in the body of the dental complex. By following the progress of the radioactive band (Fig. 3) one can easily determine directions of growth. In this instance is clearly evident that the bone is growing toward the masticatory surface (Fig. 1, MS). Another area of genesis is located along the distal margin of the dental cavity, and it can be seen that the black dotted band at this point is also progressing toward the masticatory surface. The compact hard tissue which envelops the enameloid pieces (Fig. 1, EPF) and keeps them together also progresses in the same direction.

Thus, within the dental cavity, well separated enameloid pieces (Fig. 1, EDP, E, D, and DEP) and a compact mass of supporting osteodentinic tissue (Fig. 1, ODP) are produced. Progressive mineralization occurs as this structural complex grows toward the masticatory surface. At that surface the two components (osteodentine and enameloid) are differentially worn away because of their differences in hardness.

The basal osteodentinic laminae (appearing as bars in transverse sections. Fig. 1, OBP), are formed at the periphery of the bone and grow toward the masticatory surface parallel to the direction of growth of the structural complex formed within the dental cavity. However, these laminae are resorbed by osteodentinoclasts at the floor of the dental cavity (Fig. 4). The more compact osteodentine peripheral to and forming the wall of the dental cavity is not resorbed but continues toward the masticatory surface. 
In light of the above facts, it is safe to assume that the compact type of osteodentine which forms the anteroexternal and posterointernal walls of the dental cavity progresses toward the masticatory surface, and once it surpasses the level of the dental cavity, osteodentinic tissues produced within the cavity fuse with it to form a single structural complex which continues growing towards the masticatory surface. Without the osteodentinic wall all forces applied at the masticatory surface would act upon the soft tissues that fill the dental cavity. It can thus be concluded that these walls are necessary to support the tissues produced within the dental cavity.

Histological sections show a cementing line in the form of a scar which represents the boundary between the two types of osteodentine. This can be seen in schematic Fig. 6 (CL), which is based on a series of histological sections (Fig. 5).

It is also important to emphasize that the odontoblasts, co-responsible for the production of enameloid, start producing a thin osteodentinic layer on the basal portion of this tissue after they stop producing enameloid. This osteodentinic layer fills the space between two enameloid laminae (pieces) of the same stack. Thus, this kind of osteodentine, although having the same texture as the osteodentine formed in the dental cavity has a different origin. The «tooth» of Sphoeroides is the enameloid piece plus the adjoining osteodentinic tissue in which the body of the odontoblasts are lodged (Fig. 7). The boundary between the osteodentine produced in the dental cavity and that adjacent to the enameloid piece is not easy to distinguish because both are formed and mineralized simultaneously and fuse without leaving the type of scar mentioned above. Only after very careful examination of several histological sections did we observe such a boundary.

In terms of origin, it appears that there are four types of osteodentine in the complex. (1) Laminar (trabecular) osteodentine, wich is entirely resorbed at the base of the dental cavity. (2) Parietal osteodentine, which forms the anteroexternal and posterointernal walls of the bone, and which fuses with the osteodentine produced within the dental cavity. This osteodentine is abraded at the masticatory surface. (3) Cavitary osteodentine produced by the activity of cells of the dental cavity. This is attached to the parietal osteodentine on one side and on the other side forms a compact mass enveloping the denticles. (4) Enameloidal osteodentine, which is adjacent to the enameloidal laminae, and fills the space between two successive laminae of the same stack of denticles. The utilization of these different names permits both the acurate description of the genesis of the subunits of the system, and an understanding of the dynamics of the dental complex, both poorly understood in the past.

The elements described above are very different from those found in most teleost groups which bear separated teeth. For this reason we refer to all tissues of the dental cavity and those produced from within it (i.e. the denticles and the osteodentinic mass supporting them) as the dental complex, and to the jaw-bone which is highly modified to 
support and contain the dental complex as the supporting complex. All these structures can be better visualized in Figs. 1 and 7 . There are two dental upper jaw cavities located at different levels in the upper jaw, but only one in the lower jaw. In the upper jaw the laminae of the laminar osteodentine produced at the periphery of the basal portion are partially resorbed in the lower and partially in the upper cavities. Thus, before being resorbed in the upper cavity the osteodentinic laminae are already fused to the portion of the basal complex produced in the lower cavity. From the mechanical point of view this makes the whole structure much more solid and pressure resistent, in ways that otherwise would not be possible. For example, if there existed a single wide dental cavity along with a wide masticatory surface, the walls would be weaker. The same kind of adaptation exists in many other tetraodontoid groups.

The shape of the premaxillaries and dentaries, and the shape, number and arrangement of the dental cavities and denticles vary considerably among the tetraodontoid groups (Figs. 8-14). In the Triodontidae (Fig. 8) there are no anteroexternal walls of the premaxillary and the dentary. In the Molidae (Figs. 12, 13 and 14) the posterointernal walls of the same bones and the enameloid pieces are absent. In addition, the basal unit is made of chondroid tissue. Such morphological differences apparently correlate with the feeding habits of the different species in each group.

Andreucci et al. (1982) had postulated that three basic conditions are necessary for coalescence:

1) Existence of one or more dental cavities each filled with loose connective tissue in which a large amount of supporting tissue (cavitary osteodentine) and usually teeth (enameloidal osteodentine + enameloid) are formed in the same tissue. The mass of loose connective tissue plus the solid hard tissue make up the dental complex found exclusively in fishes with coalesced teeth.

2) Presence of supporting walls, formed by solid hard tissue (parietal osteodentine), that arise from the basal portion of the premaxillary and dentary bones, fuse to the dentary complex, grow around it, and then become worn away at the masticatory surface. This typical pattern of fusion and growth is found only in fishes with coalesced teeth. Such a system is a necessity in fishes with coalesced teeth since without it the forces applied over the masticatory surface during food cutting and/or crushing would be transmitted to the soft connective tissue of the dental cavity, as noted earlier.

3) Formation of the main substance (core) of the bones from the periphery, and growth of the core in a direction parallel to the supporting walls. Since the supporting walls must grow together with the dental complex, the remaining part (i.e., the core of the bones) must have a similar development. However, part of the tissue formed at the periphery of the bones, the portion adjacent to the dental cavity, must be resorbed at the level of the floor of this cavity in order to 
guarantee its structural integrity. The remaining part of the tissue produced at the periphery but not resorbed in the dental cavity will form, as we have emphasized, the supporting walls. In summary, the set composed of bones plus dental complex will always grow in the direction determined by the forces applied over the masticatory surface. This condition is essential for maintaining the dynamics of the complex.

The three basic conditions required for coalescence may have been achieved independently in the Tetraodontoidea and in at least several other groups of fishes. Even subunits of the Tetraodontoidea have some peculiarities in the system. In Triodon, for exemple, instead of anteroexternal and posterointernal walls there are semiexternal dental cavities near the basal portion (Fig. 8). Thus, the support of the dental complex results from the fact that the cavities are distributed at different levels of the complex in such a way that the actual support comes from the osteodentinic walls located between the dental cavities. These walls thus have mechanically the same function as the anteroexternal and posterointernal walls of other tetraodontoids.

\section{COALESCENCE IN TELEOSTEI: EVOLUTIONARY CONSIDERATIONS}

Among the Teleostei coalesced teeth are also known in the Scaridae, and Oplegnathidae (Gregory, 1933: 24) in addition to the Tetraodontoidea. However, the histological structure and growth pattern is unknown in the last two families. Some scarids have coalesced teeth, but some others have conspicuous caniniform teeth and/or incisors (Schultz, 1958). In Sparisoma flavescens (Pereira Neto \& Andreucci, 1981) and Nicholsina ustus (Simões \& Andreucci, 1982 and 1983), scarids which exhibit modification of the premaxillaries and dentaries similar to those of the Tetraodontoidea, the denticles are distinct units having a core of osteodentine, pulp, and a thick layer of enameloid. As in the tetraodontoids, these coalesced denticles are united by a compact enveloping osteodentinic mass. Scarus guacamaia and Scarus trispinosus (Simões \& Andreucci, 1982 and 1983) show the same modifications, but the denticles do not have orthodentine and consequently lack a pulp chamber. Oplegnathids show, in essence, the same kind of modifications exhibited by the scarids (Isokawa et al., 1972; Inoue et al., 1973; Inage, 1975). It is safe to assume then that although not common in the Teleostei, coalescence has occurred in groups apparently not closely related phylogenetically, and that it has achieved the highest degree of complexity in the Tetraodontoidea.

The structure of teeth and bones in the Tetraodontoidea seems to reflect a specialization of an initial simple state of coalescence in which the involved structures had not undergone the profound changes evident in the highly complex state in present-day tetraodontoids. It is reasonable to assume that the ancestral tetraodontoid had a coalescent condition perhaps similar to that in Sparisoma and Nicholsina, in which the teeth are coalescent but still maintain their individual pulp cavities. 
However, it is necessary to emphasize that no known representative of the tetraodontoids, living or fossil, has such hypothetical ancestral teeth. During the evolutionary process the loss of the individuality present in the teeth of the ancestor was probably the result of the production by the loose connective tissue of the dental cavity of an osteodentinic mass (cavitary osteodentine) identical to the enameloidal osteodentine in which individual enameloid pieces can be well separated. Perhaps a reduction in the separation of the denticles was an adaptation that arose to provide an increased amount of hard enameloid on the masticatory surface. Space between the pieces has been progressively reduced, leading to the condition found in highly specialized forms such as Diodon, in which the denticles are wide plates, and Lagocephalus in which the denticles look like long ribbons.

The only living triodontid, Triodon macropterus, retains overall the most primitive characters (though derived relative to those of the hypothetical tetraodontoid ancestor), and is considered the most generalized form in the group (Tyler, 1980). It is interesting that the denticles of Triodon are similar in shape and arrangement to those of the scarids, looking like bricks in a wall, giving the anterior surface of premaxillaries and dentaries a very peculiar appearance. In the Tetraodontidae and the Diodontidae, on the other hand, the denticles are elongated or enlarged in a very characteristic fashion. In the Molidae, the enameloid pieces are absent and only the osteodentinic mass produced within the dental cavity (the cavitary osteodentine) remains.

\section{COALESCENCE IN DIPNOI}

To this point the term coalescence has been restricted to teleosts. However, the presence of plates of hard tissues within bones has also been described in non-teleostean fishes. Could the concept of coalescence as defined in this article be extended to non-teleostean groups? To investigate this possibility we began examining the Dipnoi.

Inspection of the skull of Lepidosiren paradoxa (the South American lungfish) reveals that the tooth-bearing bones classicaly called «vomer», «pterygoid», and «splenial», have a different texture than other skull bones and appear to be formed by osteodentine produced and resorbed or worn away in a fashion similar to that described for the Tetraodontoidea.

Autoradiographic studies in progress show that the maxillae of Lepidosiren demonstrates the same basic condition described for the Tetraodontoidea: a basal complex and a dental complex (Fig. 7). In the former we found osteodentinic areas at the periphery of the bone, resorption areas on the basal portion of the dental cavity, and anteroexternal and posterointernal walls that support and contain the dental complex. Instead of stacks of denticles, the dental complex contains a mass of a very hard tissue, named petrodentine by Lison (1941), enveloped by cavitary osteodentine. These grow together from the dental cavity and are worn away at the masticatory surface. The 
presence of petrodentine and the absence of stacked denticles make the dental complex structurally different from that described for certain teleostean fishes above, but its dynamics are, we think, exactly the same. Thus, the three basic conditions for coalescence as defined above are characteristic of Lepidosiren paradoxa, and by inference we deduce that the same holds trus for Protopterus, Neoceratodus, and probably also all the Dipnoi with «tooth plates». Denison (1974) shows that in the Dipnoi there are different types of tooth plates in which the shape and arrangement of the denticles differ according to the group, and suggested that the tooth plates of living lungflishes probably evolved through coalescence of the formerly scattered, separate denticles found in more primitive forms. However, he was not able to interpret correctly the structure of the «tooth plates» of the Dipnoi because of a lack of knowledge about the dynamics of growth, resorption and abrasion of both the basal and dental complexes.

\section{JAW PLATES OF PTYCTODONTID ARTHRODIRES AND HOLOCEPHALIANS}

Heavy built maxillae in which well separated teeth are not recognized are also found in fossil ptyctodontid arthrodires. Orvig (1967: 92) stated that in these fishes «there is evidence to show that in the comparatively early stages of growth the tooth plates were lined on their lateral and medial sides as well as superficially and anteriorly by a thin continuous layer composed of dentine, or sometimes of a bone-like hard tissue, and that they contained in their interior a system of spaces, wide in some cases and more narrow in others, which were separated from each other by thin trabeculae issuing from, and consisting of the same hard tissue as, the external layer just referred to».

The similarity between the tooth plates of Ctenurella (Orvig, 1967: fig. 44) and that of the Dipnoi is remarkable. Everything indicates that in ptyctodontid arthrodires there is also coalescence of teeth, and in this case, the dynamics, growth and abrasion of the structures involved might have occurred in a fashion similar to that herein described for the basal and dental complex of Teleostei and Dipnoi. This hypothesis collides amost entirely with the ideas exposed by Orvig (1967) to explain the dynamics of formation of the tooth plates of the Dipnoi and ptyctodontid arthrodires.

Orvig (1967: 92) also mentions that holocephalians, like the fishes of the groups referred to, also have a «columnar pleromic hard tissue» in the interior of the tooth plates. Studies in progress on Callorhynchus show that we can not entirely apply the model we are describing to these fishes, since the «dental complex» is not contained by a «basal complex»; the «coalescent» teeth seems to slip over the bones of the jaws in a fashion similar to an escalator, just like in other elasmobranchs. Therefore, we think that the term «basal complex», as we understand it, is not applicable in this case, and the term «dental complex» can be applied with reservations. 


\section{COALESCENCE AND ODONTODES}

It is also worth considering the possibility that dental tissues were present in the form of odontodes in the bony armor of the Agnatha prior to appearing in the mouth of the Gnathostomata. The idea that jaw teeth evolved from odontodes of the dermal plates of jawless vertebrates is expressed in almost every textbook on vertebrates. As will be shown, the explanations about the origin, structure, arrangement and wear of the odontodes based on studies of fossils by various authors is at least questionable. The current interpretation about the origin and destination of the superimposed odontodes can be summarized by quoting Alexander (1975: 79): «Fig. 3-17 (e, f) also shows crossopterygian specimens, but these do not have simple arrangement of four layers. In (e) there is a row of odontodes, one above the other, all but the topmost embedded in bone. The deepest odontodes were presumably formed first and were probably in the outer part of the dermis at the time of their formation. As the dermis thickened they came to lie deeper and deeper in it; bone was formed around them and new odontodes were formed above them, close to the new outer surface of the dermis» (Fig. 15, from Alexander, l.c.).

The idea that the more superficial odontodes in the row are younger than the deeper ones is closely associated with the notion that the hard tissue underlying them («spongy bone») would have dynamics similar to that of bony tissue covered by soft parts, rather than that of the supporting tissue of the dental complex exposed in the oral cavity we have described above. In the model we have described there is at one end of the complex a zone of formation and at the opposite end a zone of abrasion; therefore, it would be simpler to interpret the deeply located odontodes as the younger, considering that the hard tissue enveloping them grows only in one direction, towards the body surface, to the exterior.

Functionally it does not seem probable that a dermal shield with extremely hard odontodes, probably used as a protective device, would temporarily loose its function (protection) in order to allow the growth of a delicate tissue over its surface. If such a system did function then such delicate tissue would lay now new odontodes via a very slow process of mineralization, while the older basal odontodes would be gradually resorbed. It seems much more likely that the renewal process of the odontodes occurs in a fashion similar to that described for the coalescent teeth of various teleostean groups.

Fig. 15 (e and $\mathrm{g}$ ) shows that odontodes in the process of formation can be clearly recognized basal to the older odontodes already present at the surface of a cosmoid scale. For the reasons mentioned above it seems certain to us that the older odontodes are those located at the surface of the bony plate. Following the same logic we think that the interpretations about growth of ganoid scales are untenable. 
Much work remains to be done before all of these questions can be properly answered, but we are convinced that coalescence (sensu lato) is a much more common process than formerly believed. Indeed, we think the process may be very old phylogenetically, perhaps as old as the vertebrates.

\section{ACKNOWLEDGMENTS}

We are very grateful to Dr. James C. Tyler (Division of Environmental Biology, National Science Foundation, Washington, D.C.) and to Drs. Stanley H. Weitzman and Richard P. Vari (National Museum of Natural History, Smithsonian Institution, Washington, D.C.) who kindly revised the English version of the manuscript and made valuable comments and suggestions. Dr. Emily B. Giffin (The University of Wisconsin, Milwaukee) kindly sent literature unavailable to us. Dr. Tokiharu Abe (Tokaiku Fisheries Research Laboratory, Tokyo) supplied specimens of Triodon macropterus, and. Mr. Tigr Orlow made the drawings.

\section{REFERENCES}

Alexander, R. Mc. N., 1975. The chordates. 480 pp. Cambridge Univ. Press, Cambridge.

Andreucci, R.D., 1966. Aspectos morfológicos, macro e microscópicos dos dentes de Spheroides testudineus. ( $L$. 1758) (baiacu), $47 \mathrm{pp}$. Tese de Doutoramento, Faculdade de Odontologia de São José dos Campos.

Andreucci, R. D., 1968a. Aspectos anatômicos dos dentes de Spheroides testudineus. Rev. Ass. Med. Bras., 14: 245-246.

Andreucci, R. D., 1968b. Macroscopic and microscopic morphology of Spheroides testudineus teeth (checkered puffer). Acta Anat., 71: 448-471.

Andreucci, R.D., 1970. Sobre a estrutura das lojas denticulares de Spheroides testudineus (baiacu mirim). Rev. Bras. Pesquisas Med. Biol., 3: 63-67.

Andreucci, R. D. \& G. Blumen, 1971. Radioautographic study of Spheroides testudineus denticles (checkered puffer). Acta Anat., 79: 76-83.

Andreucci, R. D. \& H. A. Britski, 1969a. Macroscopic and microscopic morphology of the Mola mola teeth (sun fish). Rev. Bras. Pesquisas Med. Biol., 2: 159-162.

Andreucci, R. D. \& H. A. Britski, 1969b. Aspectos macro e microscópicos dos dentes de Lagocephalus laevigatus (baiacu arara) e de Colomesus asellus (baiacuzinho). Cienc. e Cult., 21: 483-484.

Andreucci, R. D. \& H. A. Britski, 1970. Sobre os dentes de Liosaccus intermedius (Ribeiro, 1904) e Masturus lanceolatus (Liénard, 1840). Progr. XXII Reun. Anual SBPC, Salvador, p. 305.

Andreucci, R. D. \& H. A. Britski, 1971. Dos dentes de Tetraodontidae. Progr. VIII Congr. Bras. Anat., Pelotas, p. 36.

Andreucci, R. D. \& H. A. Britski, 1975. Sobre os dentes de Diodon histrix e Chilomycterus spinosus. Cienc. e Cult., $2 \gamma$ (Supl.): 283-284.

Andreucci, R. D.; H. A. Britski \& J. Carneiro, 1974. Aspectos morfofuncionais do aparelho mastigador de Tetraodontidae e Diodontidae. Progr. X Congr. Bras. Anat., São Paulo, pp. 2-3. 
Andreucci, R. D.; H. A. Britski \& J. Carneiro, 1982. Structure and Evolution of Tetraodontoid Teeth: An Autoradiographic Study (Pisces, Tetraodontiformes). Journal of Morphology, 171: 283-292.

Bertin, L., 1958. Denticules cutanés et dents, in P. Grassé, ed., Traité de Zoologie, Vol. 13, Masson, Paris.

Britski, H. A. \& R. D. Andreucci, 1971. Sobre os dentes dos peixes Molidae. Cienc. e Cult., 24 (Suppl): 287.

Cuvier, G.L.C.F.D., 1836/1849. Le règne animal distribué d'après son organisation. 3rd, Ed., vol, 7, Masson, Paris.

Denison, R.H., 1974. The Structure and Evolution of Teeth in Lungfishes. Fieldiana, 33 (3): 31-58.

Gregory, W.K., 1933. Fish skulls. A study of the evolution of natural mechanisms. Trans. Am. Phil. Soc., (n.s.) 2s: 75-481.

Inage, T., 1975. Electron microscopic study of early formation of the tooth enameloid of a fish (Hoplognathus fasciatus). I. Odontoblasts and mairix fibers. Arch. Histol. Japonicum, 38: 209-227.

Inoue, Y., S. Uchino, T. Asano, S. Hasegawa \& F. Fujioka, 1973. The mineralization pattern of developing fish tooth enameloid using X-ray probe microanalyzer, historadiography and radioactive tracer $(45 \mathrm{Ca})$. J. Nihon Univ. Sch. Dent., 15: $52-57$.

Isokawa, S., M. Ioshida, K. Ikeda, K. Yamaguchi, K. N. Chikazawa \& S. Fujioka, 1972. Tooth enameloid formation of a fish (Hoplognathus fasciatus). Chronological relationship of matrix formation and mineralization of the enameloid and dentin. J. Nihon Univ. Sch. Dent., 14: 1-11.

Lison, L., 1941. Recherches sur la structure et l'histogenèse des dents des poissons dipneustes. Arch. Biol., 52: 279-320.

Orvig, T., 1967. Phylogeny of tooth tissues: Evolution of some calcified tissues in early vertebrates. In A.E.W. Miles, ed: Structural and chemical organization of tooth. Vol. 1, Academic Press, London, 45-110.

Owen, R., 1840/1845. Odontography; or a Treatise on the Comparative Anatomy of the Teeth, Their Physiological Relations, Mode of Development and Microscopic Structure in the Vertebrates Animals. Vol. 1, Vallière, London.

Pereira Neto, A. \& R. D. Andreucci, 1981. Estudo morfológico e funcional dos dentes do budião (Sparissoma flavescens). Rev. Odont. UNESP, 10 (1/2): 81-87.

Pflugfelder, O., 1930. Des Gebiss der Gymnodonten. Ein Beitrag zur Histogenese des Dentins. Z. Anat. Entw,-Gesch, 9.3: 543-566.

Schultz, L.P., 1958. Review of the parrotfishes. Family Scaridae. Bull. of U. S. Nat. Mus., 214: 6-17.

Simões, C. \& R. D. Andreucci, 1982. Estudo anatômico e funcional dos dentes de peixes Scaridae: Scarus trispinosus, Scarus guacamaia e Nicholsina ustus. Cienc. e Cult., 34 (1): 50-57.

Simões, C. \& R. D. Andreucci, 1983. Estudo microscópico dos dentes de peixes Scaridae: Scarus trispinosus, Scarus guacamaia e Nicholsina ustus. Cienc. e Cult., $35(6)$ : 807-815.

Tomes, C., 1914. A manual of Dental Anatomy. Blakiston, Philadelphia.

Tretjakoff, D., 1926. Die Zähne der Plectognathen. Z. Wiss. Zool., 127: 619-644.

Tyler, J. C., 1980. Osteology, phylogeny, and higher classification of the fishes of the order Plectognathi (Tetraodontiformes). NOAA Technical Report Nat.

Marine Fish. Circular, 434: 1-422. 


\section{LEGENDS FOR ILLUSTRATIONS}

Fig. 1 - Diagram of a paramedian section (X 30) near the medial suture of the articulated premaxillae (above) and dentary (below) of S. greeleyi, made as a composite of views of ground or semiserial sections of data from radioautographs. DEP, completely developed enameloid piece; EPF, enameloid piece in formation within the dental cavity; MS masticatory surface; A, B, C, D, and E, types of enameloid pieces in stacks indicated by arrows; OBP, osteodentine of the basal portion; ODP, osteodentine of the distal portion; OZ, osteodentinogenic zone (dotted area). The arrowheads outline the zone of reabsorption of the laminae and trabeculae. From Andreucci et al., 1982, fig. 1.

Fig. 2 - Simplified copy of Figure 1 showing the areas from which photomicrographs (Figs. 3-5) were obtained. SP, soft parts. From Andreucci et al., 1982, fig. 2 .

Figs. 3-5 - Paramedian sections of premaxilla and dentary of S. greeley $\imath$, injected with $3 \mathrm{H}$-proline and killed after 20 days. Haematoxylin-eosin staining. From Andreucci et al., 1982, figs. 3-5.

Fig. 3 - The radioactive band (indicated by arrows) has moved away from its site of deposition in the osteodentinogenic zone at the outer parts of the basal portion, where the osteodentinoblastic stratum (OS) is located and has moved deeper into the matrix of the laminar osteodentine (LO) toward the dental cavity. This apparent inward movement of the radioactive band was caused by the deposition of new unlabeled matrix basally after the exhaustion of the injected proline. X 300. From Andreucci et al., 1982, fig. 3 .

Fig. 4 - The osteodentinoclasts (OC) in the floor of the dental cavity resorb the laminae (L), and trabeculae of the basal portion. Note their peculiar epithelioid arrangement in the area. X 300. From Andreucci et al., 1982, fig. 4.

Fig. 5 - Compare with Figure 6. Notice the soft connective tissue (SC) in the dental cavity, the enameloid piece in formation (El), the loci of the enameloid pieces completely developed and removed by descalcification (E2-E6), and the three types of compact osteodentine in the distal portion, including parietal osteodentine (PO), eavitary osteodentine (CO), and enameloidal osteodentine (EO). The presence of autoradiograph bands in the matrix of the cavitary and enameloidal osteodentines indicates the presence of osteodentinogenic activity in that area. The parietal osteodentine does not show radioactivity, because it is already completely deposited basally at the level of the dental cavity. New layers of cavitary osteodentine are added internal to the parietal layer already deposited; and a very distinct boundary persists as a cementing line (CL) between the two types. Soft parts (SP) surrounding the basal osteodentine are seen at the right corner of the figure. As the tissues were deformed by a long process of descalcification, this photomicrograph does not conform exactly to the area shown in Figure 2. X 180. From Andreucci et al., 1982, fig. 5.

Fig. 6 - Schematic drawing of Figure 5 from which the outlines of osteodentines (parietal, cavitary, and enameloid), and cementing line are traced. From Andreucci et al., 1982, fig. 6.

Fig. 7 - Copy of Figure 1 on which the premaxillae (PM) and dentary (DE) are traced. These bones are illustrated as dark gray, whereas the dental complex containing the denticles is lighter gray. The cementing line (CL) between them is also traced. High magnification of the denticle (D) on the right side shows the enameloid (E) and the enameloidal osteodentine (EO) containing five pseudohaversian canals from which the canaliculi emerge and cross the enameloid without interruption. The canaliculi dichotomize successively, gradually decrease in diameter, and anastomose to form a thick net near the convex face of the denticle. From Andreucei et al., 1982, fig. 7. 
Figs. 8-14 - Schematic drawings of paramedian sections near the medial suture of the articulated premaxillary (above) and dentary (below). Fig. 8. Triodon macropterus; Fig. 9. Lagocephalus laevigatus; Fig. 10. Sphoeroides testudineus; Fig. 11. Diodon hystrix; Fig. 12. Mola mola (upper jaw; similar to lower jaw, omitted); Fig. 13. Masturus lanceolatus; Fig. 14. Ranzania laevis. The structures represented in figures 8 to 14 are the same as those represented in figures 1 and 7, except the chondroid tissue, which is represented by heavy stippling in 12 to 14.

Fig, 15 - Diagrams, and drawings of sections of $(a)$, (b) dermal bone of Psammosteus (a Devonian heterostracan); (c) dermal bone of Eriptychius (an Ordovician heterostracan); (d) a scale of Megalichthys (a Carboniferous crossopterygian); (e) a scale of Porolepis (a Devonian crossopterygian); ( $f$ ) dermal bone from another Devonian crossopterygian and $(g)$ a scale of Cheirolepis (a Devonian palaeoniscoid). From Alexander, 1975, figs. 3-17. 


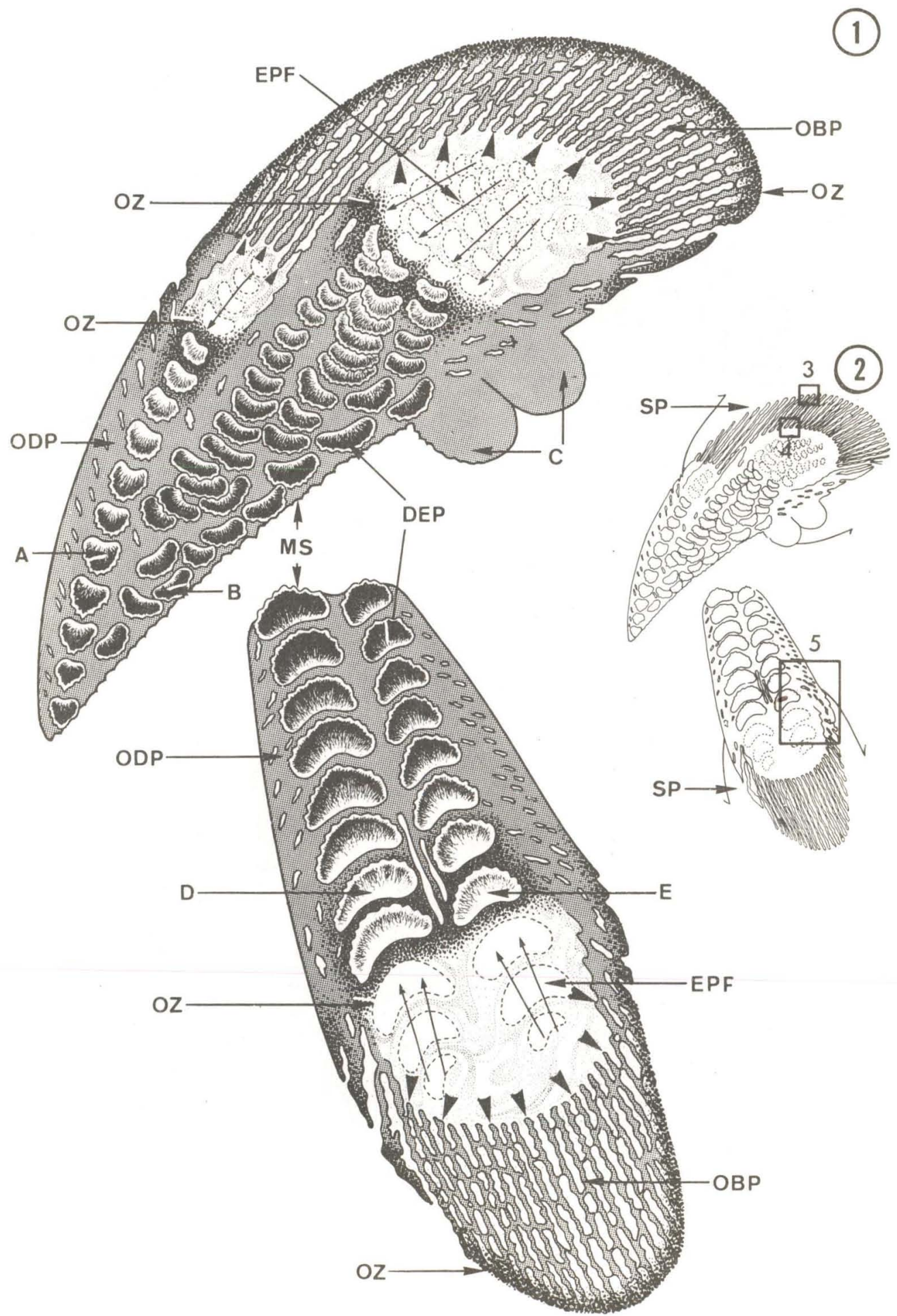




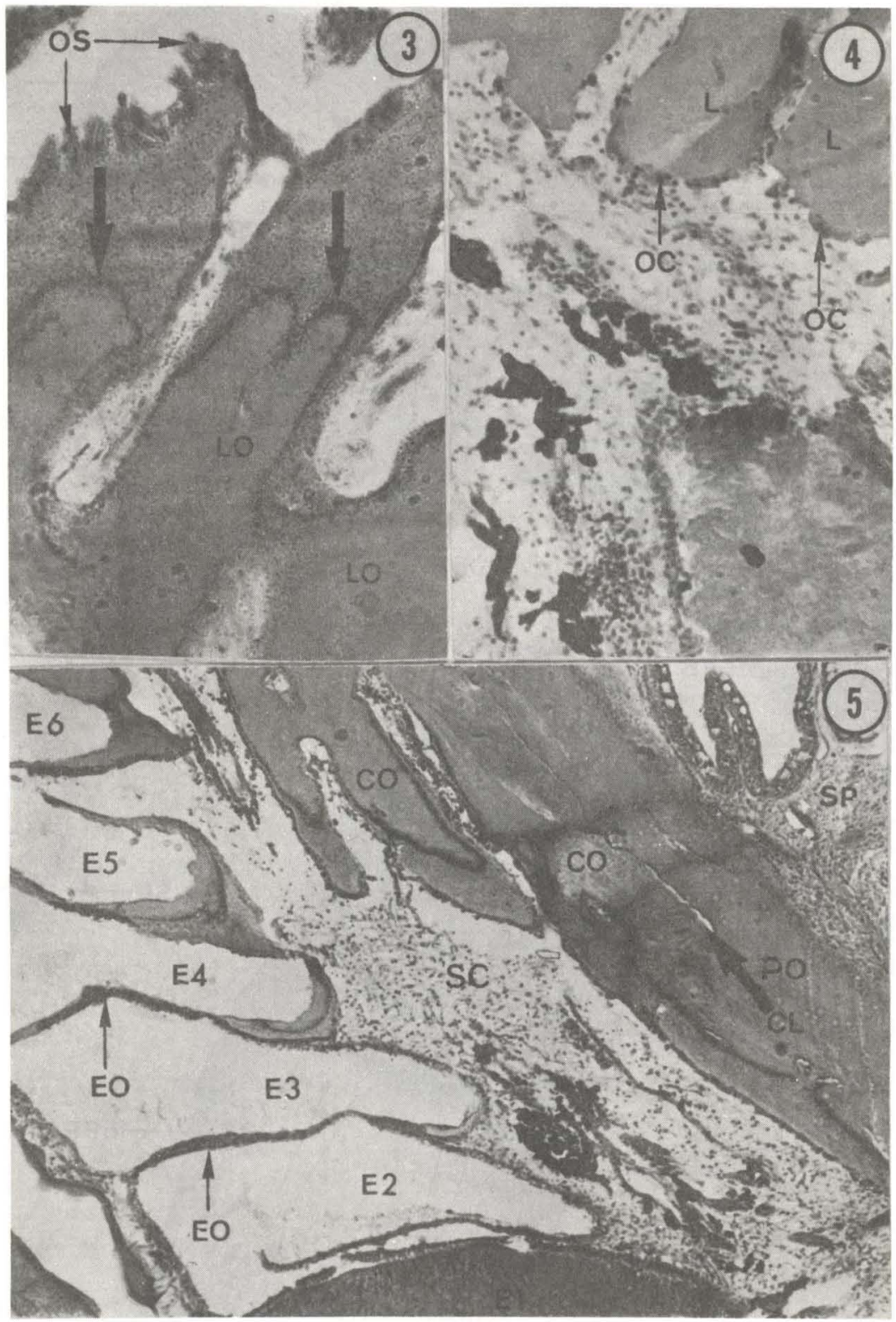




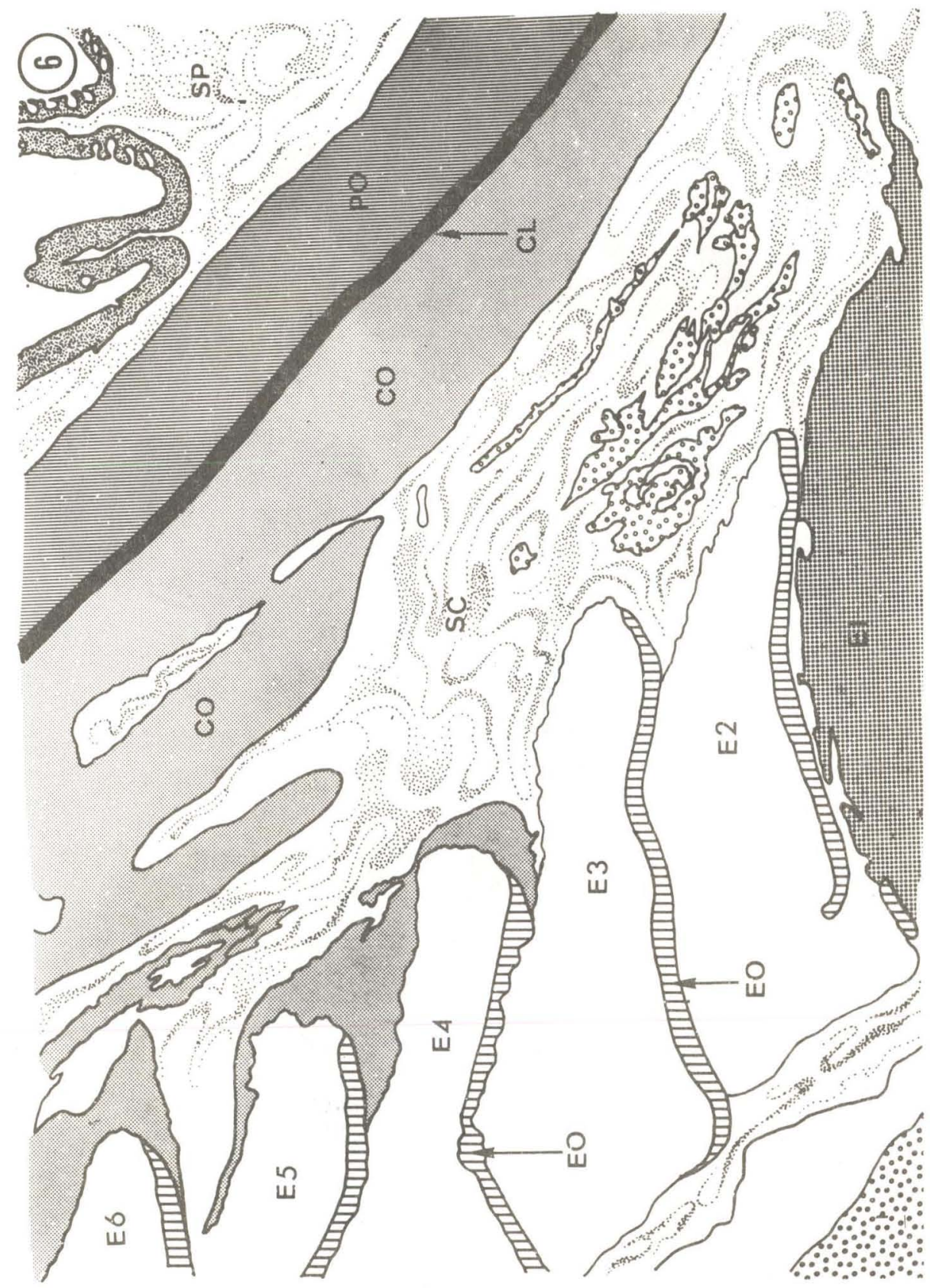




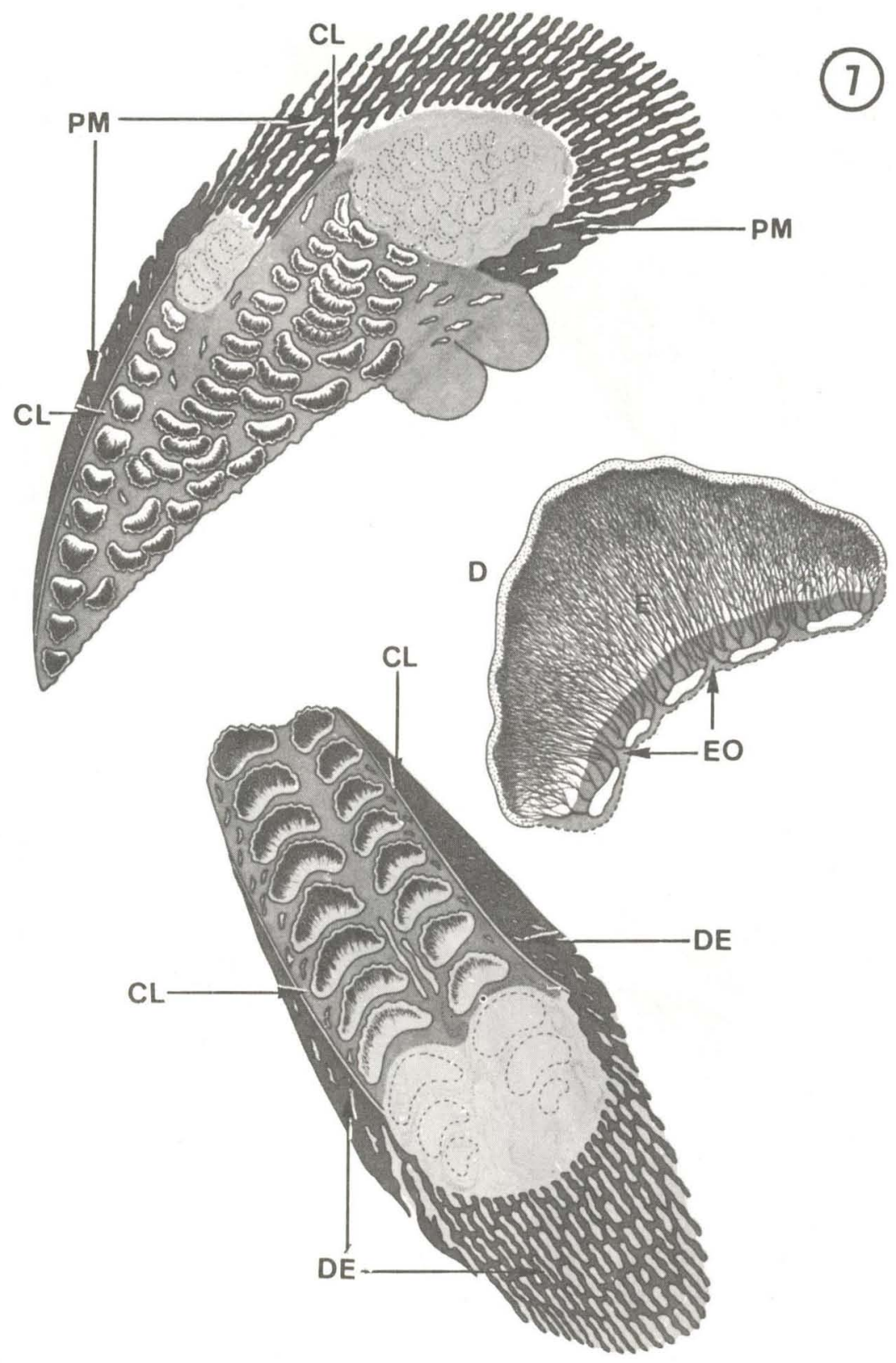




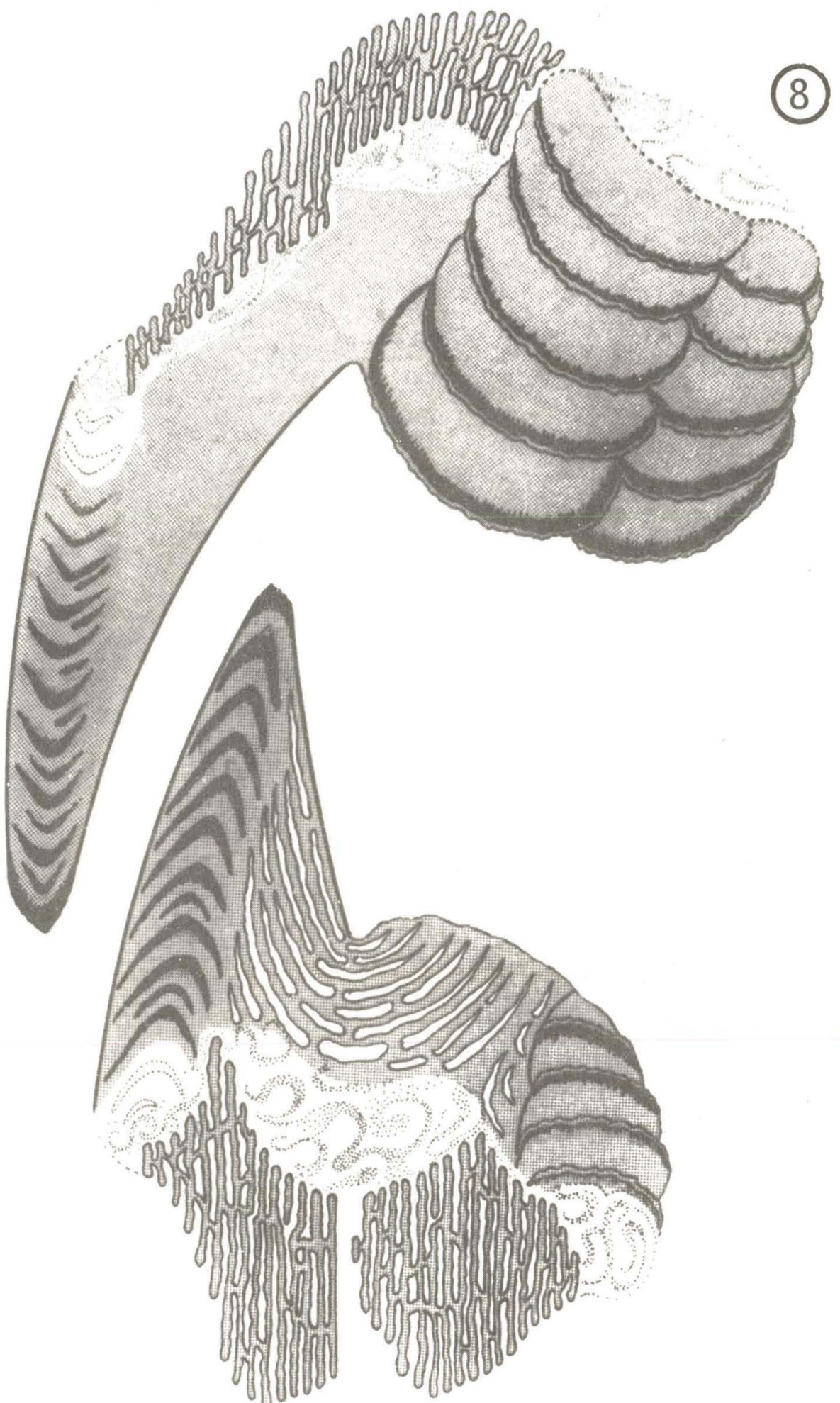




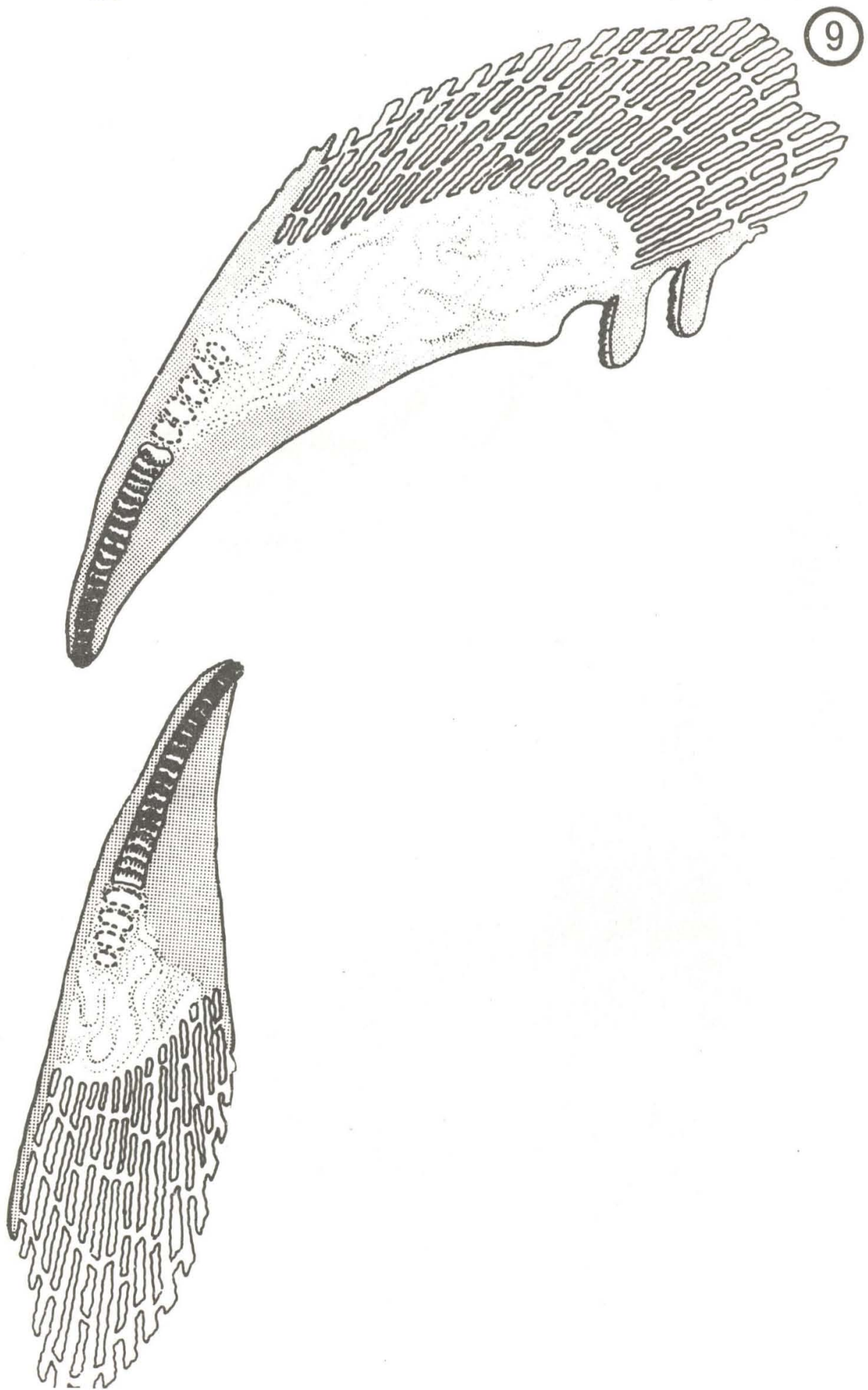




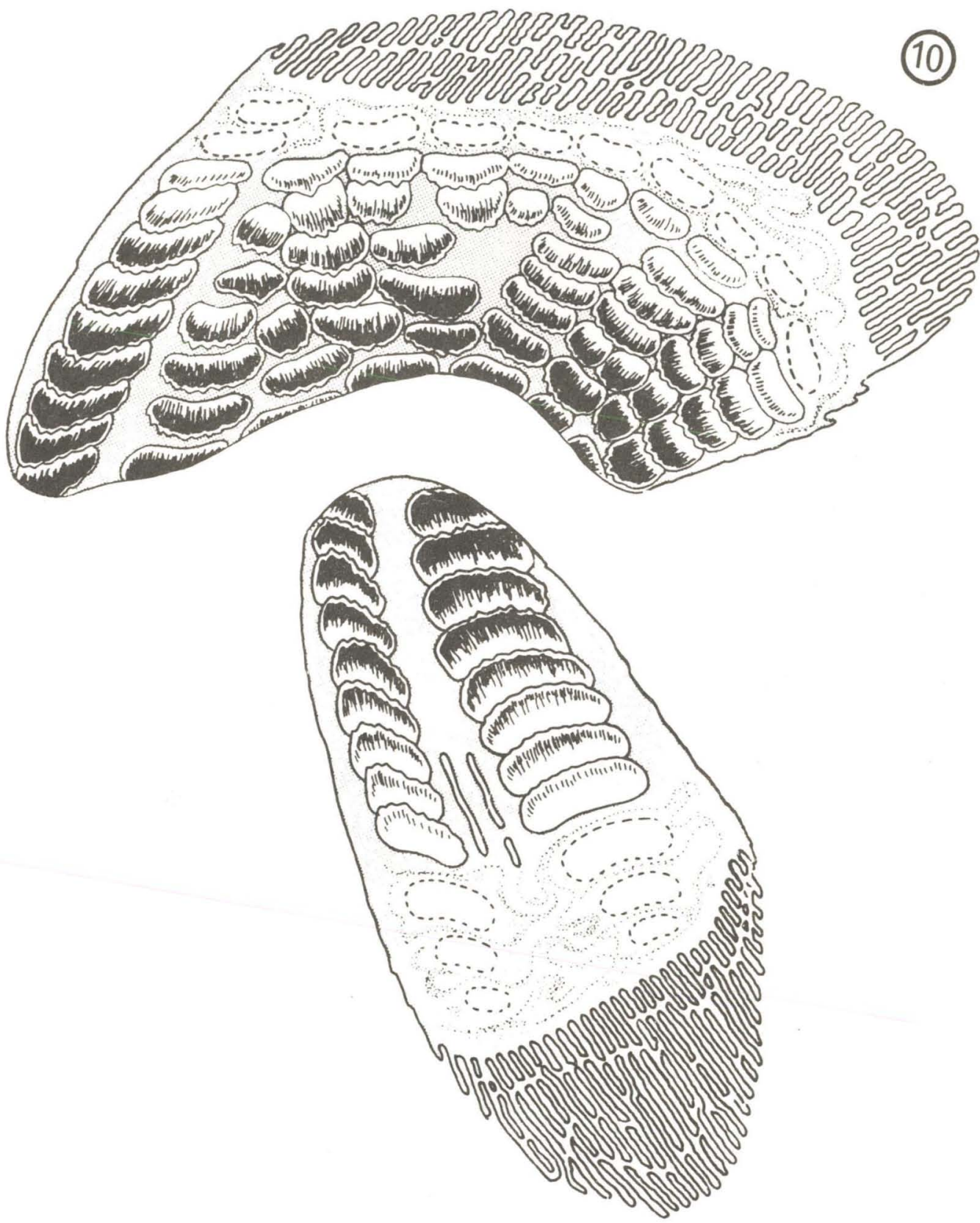



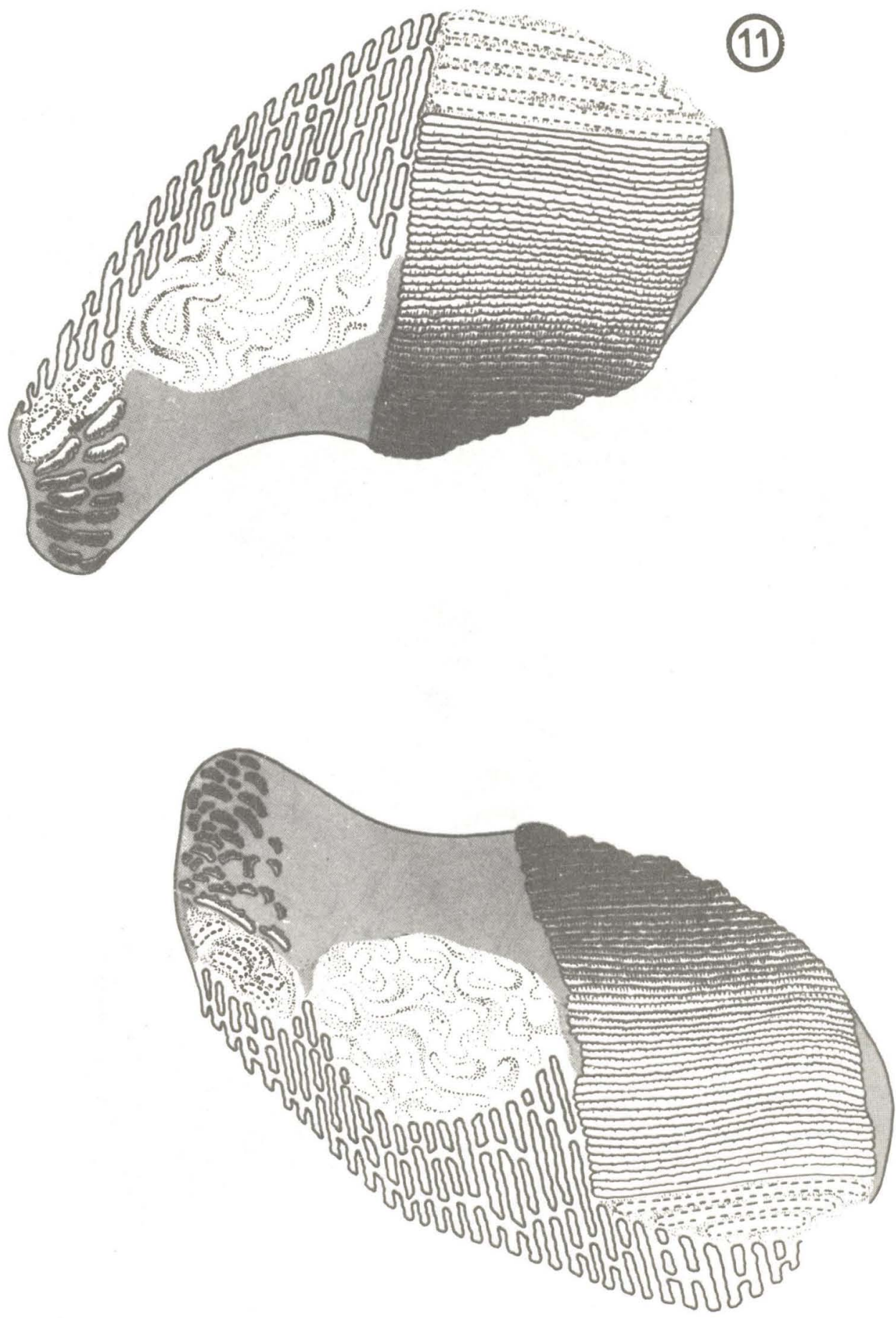


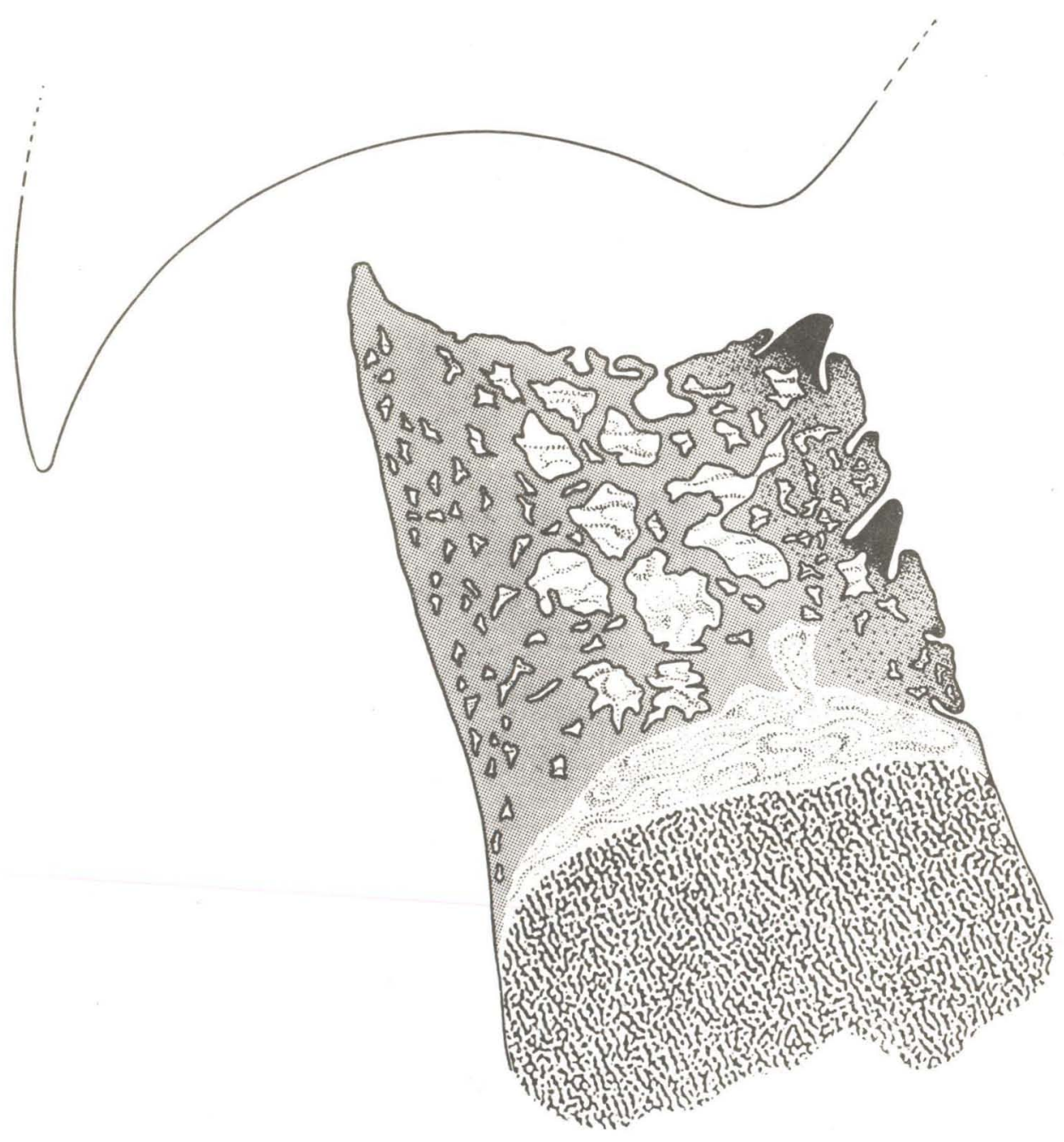


Revta bras. Zool.

482

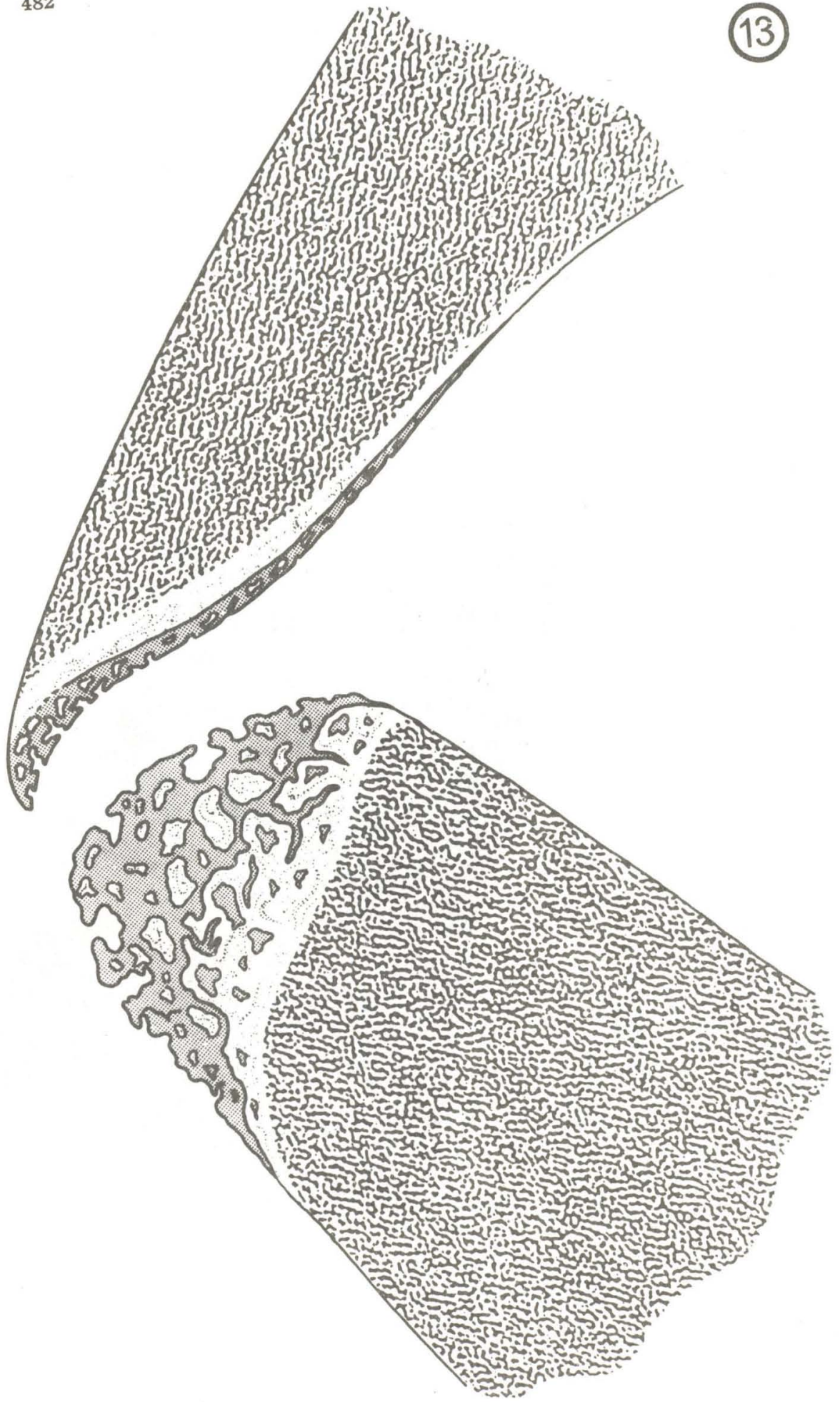


(14)
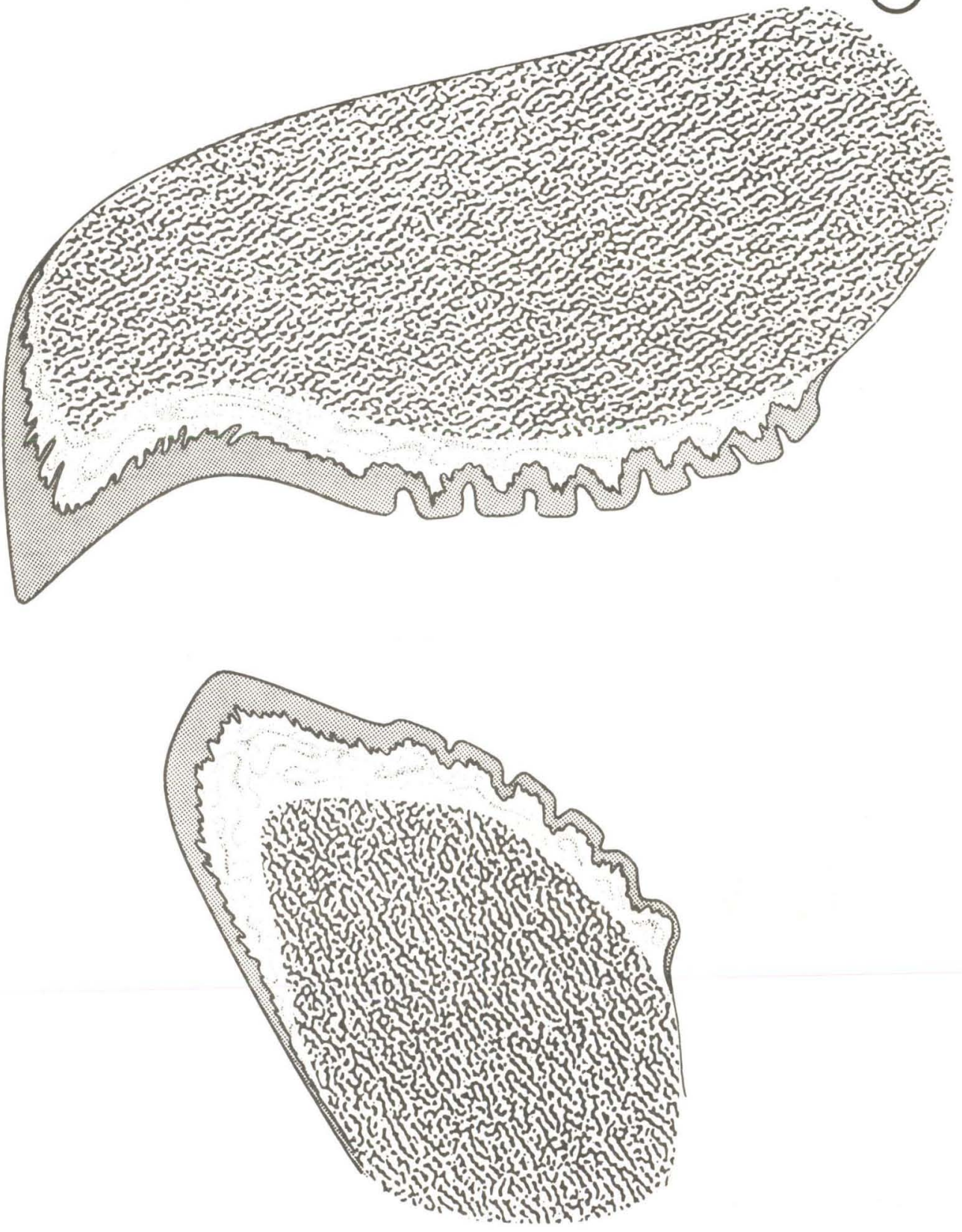
(a)

St

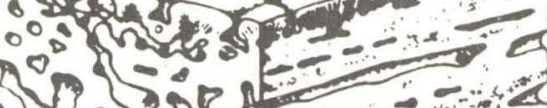
VI) $\Rightarrow 08$ o \& 205 Din

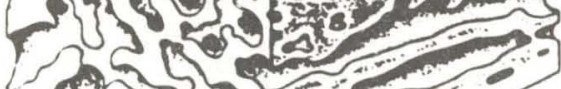
ल3 203 ?

(c)
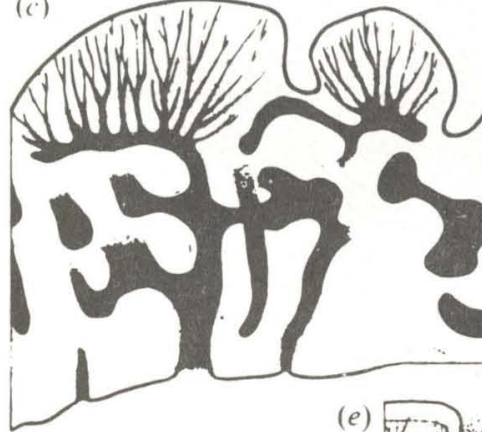

$(f)$

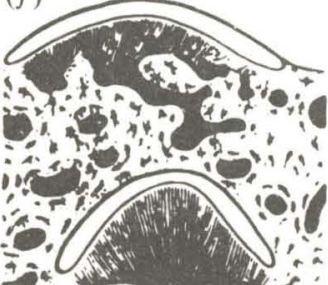
"niti to "ricio - * in

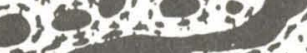
x 7 .

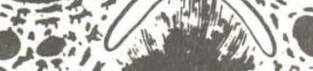
injer a Di 20 Si,

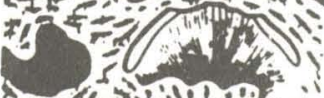
$\Rightarrow x$ s in sinh - -80.50 $1=0.0 \%$ (0) $+72=70$.

(2)

(b)
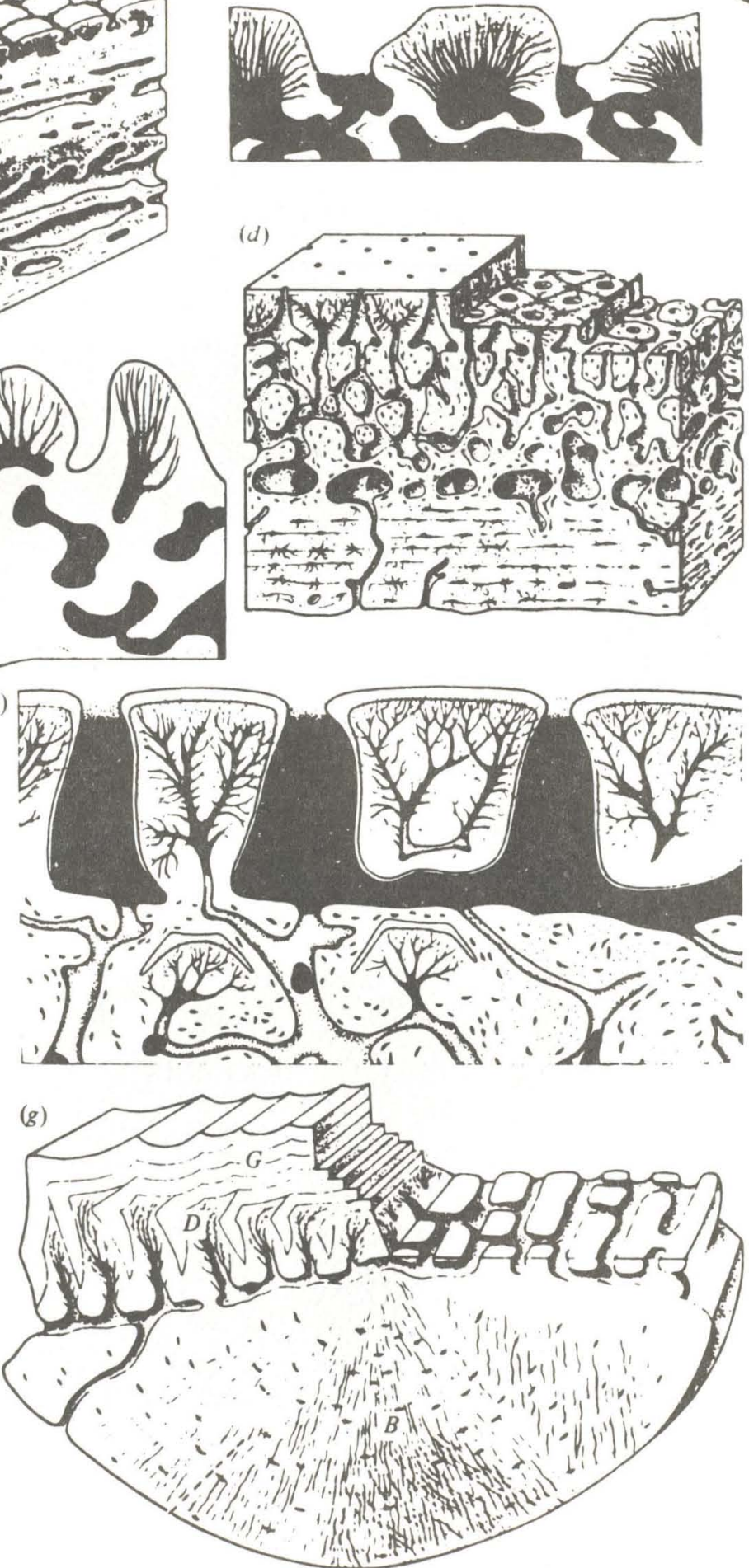